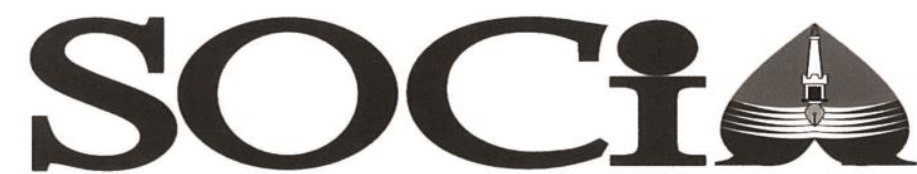

\title{
Pengaruh Model Pembelajaran Kooperatif Tipe Complex Instruction Terhadap Hasil Belajar IPS
}

\author{
YULITA DEWI PURMINTASARI, AYU LESTARI \\ IKIP PGRI Pontianak \\ yulita.dewi46@yahoo.com
}

\begin{abstract}
Abstrak
Masalah dalam penelitian ini: (1) Bagaimanakah hasil belajar IPS siswa Kelas VIII SMPN1 Selakau Kabupaten Sambas sebelum menggunakan model pembelajaran kooperatif tipe Complex Instruction, (2) Bagaimanakah hasil belajar sesudah menggunakan model tersebut, (3) Adakah pengaruh model tersebut terhadap hasil belajar siswa. Penelitian ini menggunakan metode eksperimen. Populasi berjumlah 161 siswa kelas VIII SMPN1 Selakau. Sampel dipilih menggunakan teknik cluster sampling yaitu kelas VIII-C sebagai kelas eksperimen dan kelas VIII-E sebagai kelas kontrol. Pengumpulan data menggunakan observasi langsung dan teknik pengukuran. Pengolahan data menggunakan Uji $t$. Hasil penelitian: (1) rata-rata hasil pre-test kelas eksperimen 46,718 dan kelas kontrol 43,437 , keduanya tergolong gagal, (2) rata-rata hasil post-test kelas eksperimen 76,406 dan kelas kontrol 72,031, keduanya tergolong baik, (3) hasil uji $t$ diperoleh $t_{\text {hitung }}>t_{\text {tabel }}$ yakni 2,637>2,389 maka Ho ditolak dan Ha diterima dengan taraf signifikan $\alpha=1 \%$, artinya terdapat pengaruh model pembelajaran kooperatif tipe Complex Instruction terhadap hasil belajar siswa.
\end{abstract}

\section{Kata Kunci : Complex Instruction, Hasil Belajar, Pembelajaran IPS}

\begin{abstract}
The problems in this research are: 1) How the student's learning outcomes of Social Studies grade VIII of SMPN 1 Selakau Sambas district before using cooperative learning of Complex Instruction model look like, 2) How the student's learning outcomes of Social Studies after using the cooperative learning of complex instruction model look like, 3) whether or not there is any influence of the model on student's learning outcomes. This study used an experimental method. The population include 161 students of SMPN 1 Selakau. The sample was taken using cluster sampling techniques consisting of grade VIII-C as the experimental class and VIII-E as the controlled class. Data collection techniques include direct observation and measurement. Data analysis was performed using $t$-test. The research findings are: 1) the average pre-test results of experiment class is 46,718 and controlled class is 43,437 , both results are considered fail; 2) the average post-test results of experiment class is 76,406 and controlled class is 72,031, both results are considered good; and 3) the t-test results show that $t_{\text {count }}>t_{\text {table }}$ in that $2,637>2,389$. In this case, Ho was rejected and Ha was received at significance of $\alpha=1 \%$. This means that there is an influence of cooperative learning of complex instruction model on students learning outcomes
\end{abstract}

Keywords : Complex Instruction, Learning Outcomes, Social Studies Learning 


\section{PENDAHULUAN}

\section{Latar Belakang}

Kegiatan belajar sebagai pokok dari proses pendidikan di sekolah, harus dilaksanakan dalam lingkungan dan suasana yang menarik, sehingga siswa termotivasi dan bersungguhsungguh untuk melakukan kegiatan belajar. Guru yang mampu melaksanakan tanggung jawabnya terhadap proses pembelajaran, khususnya yang berkenaan dengan penciptaan suasana belajar yang menyenangkan serta sesuai dengan tingkat kemampuan siswa, berarti telah berupaya membantu siswa untuk melaksanakan kegiatan belajar dengan optimal. Salah satu upaya yang dilakukan oleh adalah menggunakan model pembelajaran yang mampu menarik minat dan keaktifan siswa untuk melakukan kegiatan belajar.

Pemilihan

model

pembelajaran yang tepat, tidak hanya mempertimbangkan tujuan pendidikan, tetapi juga harus mempertimbangkan keaktifan, potensi dan tingkat perkembangan siswa yang beragam, serta bagaimana memotivasi siswa. Oleh karena itu, guru dituntut untuk mempunyai kreativitas yang tinggi dalam menggunakan model pembelajaran untuk menunjang tercapainya proses belajar mengajar.

Salah satu model pembelajaran yang membuat siswa lebih aktif adalah pembelajaran kooperatif. Model pembelajaran kooperatif memiliki berbagai macam model, salah satunya adalah model pembelajaran kooperatif tipe Complex Instruction. Pembelajaran Kooperatif tipe Compex Instruction merupakan model pembelajaran yang menekankan pentingnya penerapan proyek-proyek berorientasi penemuan (discovery oriented projects). Fokus utama Complex Instruction (CI) adalah membangun kepercayaan pada semua kemampuan yang dimiliki siswa. Mereka ditempatkan dalam kelompok-kelompok kooperatif dengan komposisi yang beragam 
(baik kemampuan, etnik, maupun bahasa).

Pembelajaran IPS terutama mata pelajaran sejarah masih sangat bergantung pada guru dalam proses pembelajaran sehingga kreativitas menjadi kurang berkembang secara maksimal. Siswa menganggap bahwa pelajaran IPS merupakan mata pelajaran yang cenderung berat karena IPS identik dengan hafalan dan cerita masa lampau.

Berdasarkan uraian di atas peneliti tertarik untuk melakukan penerapan model pembelajaran kooperatif tipe complex instruction dan memilih Sekolah Menengah Pertama Negeri 1 Selakau sebagai tempat penelitian. Alasan peneliti memilih Sekolah Menengah Pertama Negeri 1 Selakau Kabupaten Sambas sebagai lokasi penelitian dikarenakan sekolah ini belum pernah menerapkan model pembelajaran kooperatif tipe complex instruction. Dengan menerapkan model pembelajaran kooperatif tipe complex instruction ini diharapkan mempengaruhi aktifitas siswa yang berpengaruh juga pada hasil belajar siswa sehingga hasil belajar siswa, sehingga siswa dapat memberikan respon yang positif terhadap pembelajaran ini yang tentunya berefek dapat menumbuhkan minat belajar siswa terhadap mata pelajaran IPS.

\section{Rumusan Masalah}

Berdasarkan latar belakang yang telah dipaparkan di atas, maka yang menjadi rumusan masalah secara umum dalam penelitian ini adalah "Bagaimana Pengaruh Model Pembelajaran Kooperatif Tipe Complex Instruction Terhadap Hasil Belajar Siswa Pada Mata Pelajaran IPS Di Kelas VIII Sekolah Menengah Pertama Negeri 1 Selakau Kabupaten Sambas?".

\section{Variabel}

a. Variabel Bebas

$$
\begin{aligned}
& \text { Variabel bebas dalam } \\
& \text { penelitian ini adalah model } \\
& \text { pembelajaran kooperatif tipe } \\
& \text { complex instruction }
\end{aligned}
$$

b. Variabel Terikat

$$
\begin{aligned}
& \text { Variabel terikat dalam } \\
& \text { penelitian ini adalah hasil }
\end{aligned}
$$


belajar siswa yaitu pemahaman kognitifnya

\section{Hipotesis}

Ho: Tidak terdapat pengaruh model pembelajaran kooperatif tipe complex instruction terhadap hasil belajar siswa pada mata pelajaran IPS di kelas VIII Sekolah Menengah Pertama Negeri 1 Selakau.

Ha: Terdapat pengaruh model pembelajaran kooperatif tipe complex instruction terhadap hasil belajar siswa pada mata pelajaran IPS di kelas VIII Sekolah Menengah Pertama Negeri 1 Selakau.

\section{METODE}

\section{Bentuk Penelitian}

Metode yang digunakan dalam penelitian ini adalah metode penelitian eksperimen. Dalam penelitian eksperimen ini, peneliti menggunakan bentuk penelitian quasy-experimental designs. Arifin (2012:74) menjelaskan bahwa "dikatakan quasy-experimental designs, karena desain ini disebut juga eksperimen semu, kelas eksperimen (yang diberi perlakuan).

Rancangan penelitian yang digunakan adalah rancangan dua kelompok yaitu "Nonequivalent Control Group Design". Bentuk penelitian seperti ini dilakukan untuk membandingkan hasil sebelum dan sesudah dilakukannya perlakuan pada kelas kontrol dan kelas eksperimen. Rancangan desain penelitian ini dapat digambarkan seperti berikut:

Tabel 3.1

Bagan Rancangan Penelitian

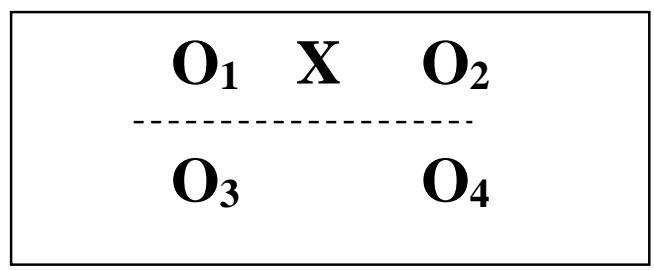

Keterangan:

$\mathrm{O}_{1}=$ Pretest kelas eksperimen (sebelum diberi perlakuan)

$\mathrm{X}=$ Perlakuan kelas eskperimen (complex instruction)

$\mathrm{O}_{2}=$ Posttest kelas eksperimen (sesudah diberi perlakuan)

$\mathrm{O}_{3}=$ Pretest kelas kontrol

$\mathrm{O}_{4}=$ Posttest kelas kontrol (Sugiyono, 2013:116) 
Yulita Dewi Purmintasari, Ayu Lestari Pengaruh Model Pembelajaran Kooperatif...

\section{Populasi dan Sampel}

Populasi dalam penelitian ini adalah seluruh siswa kelas VIII Sekolah Menengah Pertama Negeri 1 Selakau yang terdiri dari:

Tabel 3.2

Distribusi Populasi Penelitian

\begin{tabular}{|c|c|c|c|c|}
\hline \multirow{2}{*}{ No } & \multirow{2}{*}{ Kelas } & \multicolumn{2}{|c|}{ Jenis Kelamin } & \multirow{2}{*}{ Jumlah } \\
\cline { 3 - 4 } & & Laki- & Perempuan & \\
\hline 1 & VIII A & 9 & 20 & 30 \\
\hline 2 & VIII B & 14 & 19 & 33 \\
\hline 3 & VIII C & 16 & 17 & 32 \\
\hline 4 & VIII D & 16 & 18 & 34 \\
\hline 5 & VIII E & 14 & 20 & 32 \\
\hline \multicolumn{3}{|c|}{ Jumlah } & 161 \\
\hline
\end{tabular}

Dalam menentukan sampel harus dirancang sedemikian rupa dengan memperhatikan beberapa syarat dan mempergunakan teknik sampling yang dapat dipertanggungjawabkan. Setelah dilakukan uji normalitas dengan Uji Chi Kuadrat yang hasilnya adalah $\mathrm{x}^{2}$ hitung $\leq \mathrm{x}^{2}$ tabel $=3,0802 \leq 7,18$, maka kelas sampelnya adalah normal. Setelah melakukan uji normalitas selanjutnya dilakukan uji homogenitas. Hal ini dibuktikan dengan uji homogenitas menggunakan Uji Bartlett, berdasarkan hasil perhitungannya adalah $\mathrm{x}^{2}$ hitung $\leq \mathrm{x}^{2}$ tabel $=1,99 \leq$ 11,070, maka varians-varians adalah homogen.

Penentuan sampel penelitian menggunakan teknik cluster sampling. Hamid (2011:49) menjelaskan bahwa "sampel cluster adalah sampel yang dipilih secara random bukan individual, tetapi kelompok-kelompok".

Pengambilan sampel ini didasarkan pada jumlah siswa yang sama dalam kelas VIII SMP Negeri 1 Sekolah, dan terpilihlah 2 kelas sampel yang memiliki jumlah siswa yang sama yaitu kelas VIII C dan kelas VIII E. Penentuan kelas yang homogen, peneliti akan melakukan pengundian untuk memilih 1 kelas yang akan dijadikan sebagai kelas ekperimen untuk sampel penelitian dan kelas yang menjadi kelas eksperimen adalah kelas VIII C dan yang menjadi kelas kontrol adalah kelas VIII E. 
Teknik dan Alat Pengumpulan

\section{Data}

a) Panduan Observasi

Melalui panduan observasi peneliti mencatat tiap-tiap kejadian yang betapapun kecilnya telah dipandang penting dan telah ditetapkan hendak diselidiki. Dalam penelitian ini peneliti terjun langsung ke lapangan atau ke sekolah untuk mengobservasi kelas dan para siswanya.

b) Tes

Arikunto menyatakan bahwa "tes merupakan alat atau prosedur yang digunakan untuk mengetahui atau mengukur sesuatu dalam suasana, dengan cara atau aturan-aturan yang sudah ditentukan". Tes yang bisa diberikan kepada siswa dalam penelitian ini adalah tes objektif.

Berdasarkan hasil uji coba untuk mencari validitas tes diatas yang dilakukan pada kelas VIII A, maka dari 25 soal yang di uji coba yang valid sebanyak 20 soal. Sedangkan hasil uji coba reliabilitas menggunakan rumus Spearman Brown, maka diperoleh hasil uji coba berdasarkan kriteria reliabilitas yaitu $r_{\text {hitung }} 0,576>r_{\text {tabel }} 0,349$. Maka dapat ditetapkan kategori hasil uji coba termasuk kategori reliabilitas dengan interpretasi cukup.

\section{Teknik Analisis Data}

Untuk mencari pengaruh penggunaan metode Complex Instruction terhadap Hasil belajar dianalis dengan menggunakan rumus uji t. Sebagai syarat untuk melakukan uji t, terlebih dahulu dilakukan uji normalitas dan uji homogenitas.

\section{HASIL DAN PEMBAHASAN}

\section{Hasil Penelitian}

a) Hasil Belajar Sebelum Menggunakan Model Pembelajaran Kooperatif Tipe Complex Instruction

Berdasarkan
perhitungan pre-test dapat
disimpulkan bahwa rata-rata
hasil belajar siswa di kelas
ekperimen yang belum diberi




\begin{abstract}
perlakuan adalah 46,718 tergolong gagal dan nilai tersebut tidak mencapai nilai Kriteria Ketuntasan Minimum (KKM) yang telah diterpakan untuk pelajaran IPS yaitu 75 . Untuk rata-rata hasil belajar siswa kelas kontrol adalah 43,44 tergolong gagal dan nilai tersebut juga belum mencapai nilai Kriteria Ketuntasan Minimum (KKM).
\end{abstract}

\section{b) Hasil Belajar Sesudah Menggunakan Model Pembelajaran Kooperatif Tipe Complex Instruction}

Bedasarkan
perhitungan post-test dapat
disimpulkan bahwa rata-rata
hasil belajar siswa di kelas
ekperimen yang sudah diberi
perlakuan adalah 76,406
tergolong baik dan nilai tersebut
telah mencapai nilai Kriteria
Ketuntasan Minimum (KKM)
yang telah diterapkan untuk
pelajaran IPS yaitu 75 . Untuk
rata-rata hasil belajar siswa
kelas kontrol adalah 72,031
tergolong baik dan nilai tersebut

belum mencapai nilai Kriteria Ketuntasan Minimum (KKM) yaitu 75.

c) Pengaruh Hasil Belajar Terhadap Model Pembelajaran Kooperatif Tipe Complex Instruction

Perhitungan untuk mengetahui ada atau tidaknya pengaruh model pembelajaran kooperatif tipe complex instruction di kelas ekperimen yaitu dengan menggunakan Uji $t$. Sebelum melakukan Uji $t$ sebaiknya terlebih dahulu melakukan perhitungan normalitas dan homogenitas.

1) Hasil uji normalitas post-test kelas eksperimen berdistribusi normal karena $\mathrm{X}^{2}$ hitung $<\mathrm{X}^{2}$ tabel $=8,9679<$ 11,34

2) Hasil uji normalitas post-test kelas control berdiatribusi normal karena $\mathrm{X}^{2}$ hitung $<\mathrm{X}^{2}$ tabel $=6,0512<$ 11,34

3) Hasil uji homogenitas data post-test kelas kontrol dan kelas eksperimen homogen 
karena $F_{\text {hitung }}<F_{\text {tabel }}$ atau $1,095<7,50$.

4) Pengujian Hipotesis

Diketahui hasil posttest di kelas kontrol dan eksperimen adalah berdistribusi normal dan homogen, maka dilanjutkan dengan Uji $t$ untuk pegujian hipotesis dengan hasil perhitungan thitung $=2,637$ dan $t_{\text {tabel }}=2,389$, sehingga thitung $>$ tabel $=2,637>2,389$, dengan keputusan Ho ditolak dan $\mathrm{Ha}$ diterima. Artinya terdapat pengaruh model pembelajaran kooperatif tipe complex instruction terhadap hasil belajar siswa pada mata pelajaran IPS di kelas VIII Sekolah Menengah Pertama Negeri 1 Selakau Kabupaten Sambas.

\section{Pembahasan}

Model

pembelajaran

kooperatif tipe complex instruction adalah Pembelajaran Kooperatif tipe Compex Instruction merupakan model pembelajaran yang menekankan pentingnya penerapan proyek-proyek berorientasi penemuan (discovery oriented projects). Fokus utama Complex Instruction (CI) adalah membangun kepercayaan pada semua kemampuan yang dimiliki siswa. Mereka ditempatkan dalam kelompok-kelompok kooperatif dengan komposisi yang beragam (baik kemampuan, etnik, maupun bahasa). Guru memberikan keleluasaan pada mereka untuk menentukan sendiri proyek yang akan mereka libatkan dan maksimalkan (Huda, 2011:124). Sedangkan model pembelajaran berbasis proyek merupakan pembelajaran yang melibatkan siswa secara aktif dalam merancang tujuan pembelajaran untuk menghasilkan produk atau proyek yang nyata (Sutirman, 2013,43).

Sebelum memberikan perlakuan pada kelas ekperimen (VIII C) dan kelas kontrol (VIII E) terlebih dahulu kelas ekperimen dan kelas kontrol diberi pre-test. 
Yulita Dewi Purmintasari, Ayu Lestari Pengaruh Model Pembelajaran Kooperatif...

Pre-test diberikan untuk sebelum masuk ke proses belajar mengetahui kemampuan awal siswa pada kelas eksperimen dan kontrol. Setelah pre-test dilakukan selanjutnya memberikan perlakuan kepada kelas eksperimen dengan menggunakan model pembelajaran kooperatif tipe complex instruction dan untuk kelas kontrol tidak menggunakan model pembelajaran kooperatif tipe complex instruction tetapi menggunakan model pembelajaran berbasis proyek.

Awalnya guru masuk ke dalam kelas eksperimen dan kelas kontrol sesuai jadwal yang ada. Sebelum guru melakukan perlakuan terhadap kelas eksperimen dan kelas kontrol terlebih dahulu guru melakukan kegiatan eksplorasi sesuai dengan kegiatan di RPP. Setelah kegiatan eksplorasi barulah guru memberikan soal pre-test kepada kelas eksperimen dan kelas kontrol. Pre-test ini dilakukan dengan tujuan untuk mengetahui tingkat awal kemampuan siswa mengajar.

Hasil yang diperoleh dari data pre-test, dapat dilihat dengan ratarata nilai pre-test kelas eksperimen sebesar 46,718 dapat dikatakan gagal, dengan standar deviasi 13,38 dan rata-rata hasil pre-test kontrol sebesar 43,437 dapat dikatakan gagal, dengan standar deviasi 11,82. Hasil ini diperoleh dari kedua kelas (kelas ekperimen dan kelas kontrol) sebelum mendapat perlakuan. Hasil yang diperoleh dari pengolahan data pre-test kelas eksperimen dan kelas kontrol ternyata rata-rata hasil belajar siswa dibawah kriteria ketuntasan minimal (KKM). Setelah pre-test dilakukan, maka selanjutnya adalah memberikan perlakuan kepada siswa di kedua kelas, yang mana kelas yang satu (kelas eksperimen) menggunakan model pembelajaran kooperatif tipe complex instruction dan kelas kontrol diberi perlakuan menggunakan model pembelajaran berbasis proyek. 
Dalam

memberikan

perlakuan terhadap kelas

eksperimen, peneliti memberikan

model pembelajaran kooperatif

tipe complex instruction kepada

siswa sesuai dengan langkah-

langkah yang telah dijelaskan

dalam teori, yaitu: guru

menyiapkan materi pembelajaran,

guru membagi kelompok, guru

menjelaskan materi secara singkat,

siswa mulai diskusi kelompok,

siswa melakukan presentasi di

depan kelas, dan evaluasi

(Warsono, 2012: 209). Selain guru

menerapkan model pembelajaran

kooperatif tipe complex instruction,

guru pun melakukan observasi

terhadap siswa saat proses belajar

mengajar berlangsung di dalam

kelas.

Untuk perlakuan di kelas

kontrol guru menerapakn model pembelajaran berbasis proyek. Langkah-langkah dari model pembelajaran berbasis proyek itu sendiri adalah membentuk kelompok diskusi, membuat desain rencana proyek, membuat jadwal pelaksanaan

kegiatan pembelajaran, selama siswa bekerja dalam kelompoknya guru memantau kegiatan tiap kelompok, setelah selesai berdiskusi setiap kelompok ditunjuk untuk maju ke depan atau yang mewakili kelompok untuk mempresentasikan hasil tugas kelompoknya, kemudian kelompok lain menanggapinya diskusi hasil kerja kelompoknya, dan menilai hasil kerja siswa (Sutirman, 2013: 46).

Kemudian setelah memberikan perlakuan selesai, maka langkah selanjutnya adalah memberikan tes akhir (post-test) kepada siswa. Post-test ini diberikan untuk mengetahui kemampuan hasil belajar siswa dikelas eksperimen dan kelas kontrol setelah mendapat perlakuan. Post-test diberikan kepada kelas eksperimen dan kelas kontrol. Dari hasil olah data yang diperoleh nilai rata-rata kelas eksperimen post-test sebesar 76,406 tergolong baik dengan standar deviasi 7,868. Hasil yang diperoleh dari pengolahan data 
post-test kelas eksperimen ternyata rata-rata hasil belajar siswa diatas kriteria ketuntasan minimal (KKM). Untuk kelas konrol nilai rata-rata post-test sebesar 72,031 tergolong baik dengan standar deviasi 8,24. Secara keseluruhan kelas kontrol ini nilai rata-ratanya belum mencapai kriteria ketuntasan minimal (KKM).

Walaupun nilai rata-rata siswa pada kelas eksperimen sudah mencapai angka kriteria ketuntasan minimal (KKM), tetapi masih ada siswa yang belum mencapai nilai KKM secara individunya. Untuk kelas eksperimen atau kelas kontrol dan seluruh kelas yang nilai keseluruhannya belum mencapai KKM, maka bisa dilakukan tindakan selanjutnya yaitu melakukan remedial atau perbaikan nilai. Remedial ini dilakukan dengan memberikan tugas atau tes kepada siswa untuk memperbaiki nilai mereka yang belum mencapai angka kriteria ketuntasan minimal (KKM).
Selanjutnya untuk menghitung uji $t$ maka terlebih dahulu menghitung data post-test dengan chi kuadrat untuk mrngetahui data post-test kelas eksperimen dan kelas kontol itu termasuk ke data normal. Dari data kelas eksperimen dan kelas kontrol yang berdistribusi normal dan homogen, kemudian didapatlah thitung dengan rumus uji $t$ sebesar 2,637 dengan tabel sebesar 2,389, diperoleh bahwa thitung $>$ tabel yakni 2,637 > 2,389, maka Ho ditolak dan Ha diterima. Hal ini bearti terdapat pengaruh model pembelajaran koopertaif tipe complex instruction terhadap hasil belajar siswa pada mata pelajaran IPS di kelas VIII Sekolah Menengah Pertama Negeri 1 Selakau Kabupaten Sambas.

\section{SIMPULAN}

Berdasarkan hasil analisis data dapat disimpulkan bahwa Rata-rata hasil pre-test pada kelas eksperimen adalah sebesar 46,718 yang tergolong gagal dengan standar deviasi 13,38 . Untuk ratarata pre-test kelas kontrol sebesar 
43,437 juga tergolong gagal dengan standar deviasi 11,82.

Rata-rata hasil post-test pada kelas eksperimen adalah sebesar 76,406 tergolong baik dengan standar deviasi 7,868. Untuk ratarata hasil post-test pada kelas kontrol sebesar 72,031 juga tergolong baik dengan standar deviasi 8,24.

Dari hasil uji hipotesis dengan menggunakan uji $t$ dengan $\alpha=1 \%$ diperoleh thitung $>$ ttabel yakni 2,637 > 2,389, Ho ditolak dan Ha diterima maka dapat disimpulkan bahwa terdapat pengaruh model pembelajaran kooperatif tipe complex instruction pada mata pelajaran IPS di kelas VIII Sekolah Menengah Pertama Negeri 1 Selakau Kabupaten Sambas.

\section{UCAPAN TERIMA KASIH}

Dalam kesempatan ini penulis mengucapkan terima kasih kepada berbagai pihak yang telah membantu dalam pelaksanaan penelitian, khususnya pihak SMPN1 Selakau Kabupaten Sambas. Penulis juga mengucapkan terima kasih kepada dewan redaksi Jurnal Socia atas kesempatan yang diberikan sehingga paper ini dapat diterbitkan pada Jurnal Socia edisi Juni 2016.

\section{DAFTAR PUSTAKA}

Arifin, Z. 2012. Penelitian Pendidikan. Bandung: Remaja Rosdakarya.

Arikunto, S. 2010. Dasar-Dasar Evaluasi Pendidikan. Jakarta: PT Bumi Aksara.

Hamid, D. 2011. Metode Penelitian Pendidikan. Bandung: Alfabeta.

Huda, M. 2011. Cooperative Learning. Yogyakarta: Pustaka Pelajar.

Sugiyono. 2013. Metode Penelitian Pendidikan Pendekatan Kuantitatif, Kuaitatif, dan $R \& D$. Bandung: Alfabeta.

Warsono. 2012. Pembelajaran Aktif, Teori dan Asesmen.Bandung: Remaja Rosdakarya.

Sutirman. 2013. Media dan ModelModel Pembelajaran Inovatif. Yogyakarta: Graha Ilmu. 